would certainly lead any one acquainted with the subject to believe that he had acted on it. The only clues afforded by the work which indicate that the Owenian system was not adopted in its entirety, now pointed out by Mr. Lydekker as existing at pp. 152, 174, would certainly escape the notice of any one who had not actually spelled through the work, as I feel sure whoever will take the trouble to refer to will agree with me.

There is no evidence whatever to support Mr. Lydekker's assumption that the two anterior premolars in Vespertilio and the anterior premolar in Rhinolophus correspond, respectively, to $p m s, 2$ and 3 and to $p .3$ of the typical series. On the contrary, the small size of the second premolar in Vespcrtilio points to reduction by loss from the middle of the series, as we find in the greater number of species of the closely-allied order, Insectivora, and, as we know, takes place in the mandible of several species of Chiroptera.

With reference to the wish expressed in the review that, instead of writing a mere catalogue of the fossil mammals in the British Museum, Mr. Lydekker had undertaken one of all the known species, and his objection, while regretting that the intended friendly estimate of his capability for such a work has been so hostilely received, 1 maintain that such should have been undertaken; but Mr. Lydekker's remarks show how necessary it is, and that the objection that new genera and species are being made almost daily (it is probable that they will continue to be be made to the end of time) might be applied with equal force on behalf of the birds by Mr. Sharpe, who nevertheless continues his excellent catalogue. It is only by the publication of such a work that we can hope to limit the mantifacture of "empty names," such as Mr. Lydekker objects to, and to reduce to order the vast amount of scattered information and contesting opinions which encumber the study of the subject. THE REVIEWER

\section{THE ORCHID EXHIBITION}

THE Exhibition held in the Conservatory at South Kensington on the 12 th and $13^{\text {th }}$ inst. in connection with the Orchid Conference of the Royal Horticultural Society, must have furnished to the least observant visitor some explanation of the fascination exercised by orchids over their cultivators. The beauty, the variety, the strangeness of the flowers of the Orchideæ attract and interest the least enthusiastic even of the lovers of nature. But the variation in flower, compatible with botanical inclusion in one family, is not more marked than is the difference in mode of flowering and of growth. Could there be in one natural order a stronger contrast than between the mode of growth and the gorgeous flowers of the genus Cattleya-essentially "flaunting flowers"-and those of the genus Masdevallia, where the conspicuous part of the flower consists of the three sepals, drawn out in many species into thread-like tails many inches long, and ranging in colour through every shade of orange, scarlet, and purple, down to an almost inky black!

While a larger array of specimen plants has often been seen than was shown at the Conference, there has never been gathered together in any country so varied and interesting a collection, nor one containing so many rare and curious plants. Great as was the interest for the cultivator, it was no less great for the botanist. Mr. Ridley, of the Natural History Museum, who, in conjunction with $\mathrm{Mr}$. Burbidge, of the Dublin Botanic Gardens, has undertaken to draw up a report on the Conference Exhibition, found that sixty-one genera of orchids were represented. For the first time in the history of flower-shows there was a numerous collection of hybrid orchids, raised by artificial fertilisation, in flower. For the first time was there a large collection of orchids in fruit. The progress of hybridisation, greatly due to the energy and skill of Messrs. Veitch and Sons and their intelligent foremen, Mr. Dominy and Mr. Seden, has already been fertile in valuable results for the cultivator. An excellent little book lately published, gives a list of eighty-nine hybrids already in cultivation, I "Orchids: a Review of their Structure and History," Illustrated. By
Lewis Castle. (Journal of Horticulture Office, $17 \mathrm{I}$, Fleet Street, E.C.) distributed among twelve genera; but thirty-seven of them belonging to the genus Cypripedium. Those who are privileged to enter the penetralia at Chelsea know that there are there and elsewhere great numbers and varieties of hybrids, which are slowly surmounting the dangers and delicacy of infancy and childhood.

But the labours of the hybridiser promise to be of great value to the botanist. Mr. Harry Veitch, in his very suggestive and interesting paper on the "Hybridisation of Orchids," read at the Conference, says: "How will these bigeneric crosses affect the stability of the genera as at present circumscribed?" It is well established already that the genera Lœlia and Cattleya cross freely with one another, and $\mathrm{Mr}$. Veitch refers in his paper to two other bigeneric hybrids, which have already flowered, and to others which have been raised, but have not yet flowered.

Unfortunately it must be a long time before orchid cultivators generally can enjoy the results of hybridisation. $\mathrm{Mr}$. Veitch gives the time the hybridist must wait to see the result of his labours, as follows:-

\begin{tabular}{|c|c|c|c|c|c|}
\hline Genus. & & & & & $\begin{array}{c}\text { Time from Germinatio } \\
\text { to Flowering }\end{array}$ \\
\hline Dendrobium & $\cdots$ & $\cdots$ & .. & ... & 3 to 4 years. \\
\hline Phaius ... & $\ldots$ & $\ldots$ & ... & $\cdots$ & About the same. \\
\hline Calanthe & $\ldots$ & $\cdots$ & $\cdots$ & $\cdots$ & \\
\hline Masdevallia & $\ldots$ & $\cdots$ & ... & $\cdots$ & 4 to 5 years. \\
\hline Chysis ... & $\cdots$ & $\cdots$ & ... & $\cdots$ & \\
\hline Zygopetalum & $\ldots$ & $\ldots$ & $\ldots$ & $\ldots$ & 5 to 9 years. \\
\hline Lycaste ... & $\ldots$ & $\ldots$ & ... & $\cdots$ & 7 to 8 years. \\
\hline Lœlia $\quad .$. & $\cdots$ & $\cdots$ & $\cdots$ & $\cdots$ & Io to 12 years. \\
\hline Cattleya & ... & $\ldots$ & $\ldots$ & $\cdots$ & 年 \\
\hline
\end{tabular}

With the exception of the genera Dendrobium and Cypripedium, it is a long time before sufficient plants of a hybrid can be obtained for distribution, even under the most skilful cultivation. For this reason many of the more beautiful hybrids will probably remain scarce and valuable for years. The high prices paid by collectors for orchids in some cases have been a source of merriment to the uninitiated. Speaking generally, orchids were never so cheap or so plentiful. But if a collector must have a hybrid which has been raised by skilful hands and nursed into vigour by years of patient care-or, on the other hand, must have a beautiful natural variety which has been picked out of millions of plants-if he must have them, he must pay for them.

The Royal Horticultural Society is to be congratulated both on the botanical and the horticultural results of the late Conference. The Conference was a new idea, a new departure. It has demonstrated the great, widespread, and, better still, the intelligent interest taken in a singular and beautiful natural order, and the skill brought to bear on its cultivation.

The short scientific contributions of Prof. Reichenbach, whose absence was universally regretted; the paper on "Hybridisation," by Mr. Veitch, and the brief discussion which ensued, were listened to by a large and appreciative conference. The paper on "Cultivation," by Mr. O'Brien, was also interesting and valuable. The very difficult question of nomenclature, which is in so confused and unsatisfactory a state as to ill brook delay, was postponed. It could not be discussed with advantage at the tail of a long meeting, and will be referred, it is to be hoped, to a a scientific committee selected from botanists in and out of the Royal Horticultural Society.

T. L.

\section{WHEAT-PRODUCTION IN INDIA ${ }^{1}$}

NDIA has recently exhibited her extraordinary powers as a wheat-producing area of vast extent. Up to the year 1877 the British wheat-grower looked upon the exhaustless prairies of the far West as his most formid-

$t$ The Wheat-Production and Trade of India. Calcutta. Being a collection of correspondenee in continuation of papers published in 1879 . 